\title{
PERLINDUNGAN HUKUM TERHADAP PARA PELAKU WHISTLE BLOWER PADA TINDAK PIDANA KORUPSI
}

\author{
Dian Eka Kusuma Wardani
}

Fakultas Hukum Universitas Sawerigading Makassar

\begin{abstract}
The growth of corruption cases in Indonesia is very fast compared to the disclosure. Today there is a new phenomenon in the world of law where the emergence of someone who dared to reveal the facts behind the criminal act of corruption. The fact discoverer can be called a whistle blower. Whistle blower is usually addressed to someone who first discloses or reports a criminal offense or action that is considered illegal. Such disclosure is not always based on the reporter's good faith but the purpose of exposing the crime or misappropriation he or she knows. This research uses normative juridical research method. Data processing method used is descriptive qualitative method with normative juridical approach that is studying related literatures, opinion of related lawyer and case analysis in documents to clarify result of research. This study aims to determine the form of protection for whistle blower in the criminal justice system in Indonesia. The conclusion of the result of this research is the right form of legal protection for whistle blower in the criminal justice system in Indonesia that is repressive and preventive. Repressive protection in the form of activation of Witness and Victim Protection Institution while preventive protection in the form of revision of stages of criminal justice process in Indonesia and the formulation of laws that specifically regulate legal protection for whistle blower.
\end{abstract}

Keywords:

Whistle blower, Corruption, Legal protection

\begin{abstract}
Abstrak
Pertumbuhan kasus korupsi di Indonesia sangatlah cepat dibandingankan dengan pengungkapannya. Saat ini muncul fenomena baru dalam dunia hukum dimana munculnya sesesorang yang berani mengungkap fakta di balik terjadinya tindak pidana korupsi. Sang pengungkap fakta dapat di sebut dengan whistle blower. Whistle blower biasanya di tujukan kepada seseorang yang pertama kali mengungkap atau melaporkan suatu tindak pidana atau tindakan yang di anggap
\end{abstract}


illegal. Pengungkapan tersebut tidak selalu didasari itikad baik sang pelapor tetapi tujuannya untuk mengungkap kejahatan atau penyelewengan yang diketahuinya. Penelitian ini menggunakan metode penelitian yuridis normatif. Metode pengolahan data yang digunakan adalah metode deskriptif kualitatif dengan pendekatan yuridis normatif yaitu mengkaji literatur-literatur yang berkaitan, pendapat para ahli hukum terkait dan analisa kasus dalam dokumen-dokumen untuk memperjelas hasil penelitian. Penelitian ini bertujuan untuk mengetahui bentuk perlindungan bagi whistle blower dalam sistem peradilan pidana di Indonesia. Kesimpulan dari hasil penelitian ini bentuk perlindungan hukum yang tepat bagi whistle blower dalam sistem peradilan pidana di Indonesia yaitu bersifat represif dan preventif. Perlindungan yang bersifat represif berupa aktivasi Lembaga Perlindungan Saksi dan Korban sedangkan perlindungan yang bersifat preventif berupa revisi tahapan proses peradilan pidana di Indonesia dan pembentukan undang-undang yang secara khusus mengatur perlindungan hukum bagi whistle blower.

\section{Kata Kunci:}

Whistle blower, Korupsi, Perlindungan hukum

\section{A. PENDAHULUAN}

\section{Latar Belakang}

$\mathrm{B}$ erbicara tentang korupsi sebenarnya bukanlah masalah baru di Indonesia. Bahkan berbagai kalangan menilai bahwa korupsi telah menjadi bagian dari kehidupan, menjadi suatu sistem dan menyatu dengan penyelenggaraan pemerintahan negara. Penanggulangan korupsi dengan menggunakan perangkat perundang-undangan yang ada masih banyak menemui kegagalan. Keadaan demikian akan menggoyahkan demokrasi sebagai sendi utama dalam kehidupan berbangsa dan bernegara, melumpuhkan nilai-nilai keadilan dan kepastian hukum serta semakin jauh dari tujuan tercapainya masyarakat sejahtera. Dengan melihat latar belakang timbulnya korupsi, salah satu faktor yang menyebabkan meningkatnya aktivitas korupsi di beberapa negara disebabkan terjadinya perubahan politik yang sistemik, sehingga tidak saja memperlemah atau menghancurkan lembaga sosial politik, tetapi juga lembaga hukum.

Korupsi pertama kali dianggap sebagai tindak pidana di Indonesia berdasarkan Undang-Undang No. 24 Prp. Tahun 1960 tentang Pengusutan, Penuntutan, dan Pemeriksaan Tindak Pidana Korupsi. Dalam kenyataannya undang-undang ini tidak mampu melaksanakan tugasnya sehingga dicabut dan diganti dengan UndangUndang No. 3 Tahun 1971 tentang Pemberantasan Tindak Pidana Korupsi, dan terakhir sejak tanggal 16 Agustus 1999 diganti dengan Undang-Undang No. 31 Tahun 1999 sebagaimana diubah dan ditambah dengan Undang-Undang No. 20 
Tahun 2001 tentang Pemberantasan Tindak Pidana Korupsi. Dalam arti harfia, korupsi dapat berupa: (1) Kejahatan kebusukan, dapat disuap, tidak bermoral, kebejatan, dan ketidakjujuran, (2) Perbuatan yang buruk seperti penggelapan uang, penerimaan sogok dan sebagainya, (3) Korup (busuk; suka menerima uang suap, uang sogok; memakai kekuasaan untuk kepentingan sendiri dan sebagainya.

Whistle blower biasanya ditujukan kepada seseorang yang pertama kali mengungkap atau melaporkan suatu tindak pidana atau tindakan yangdianggap ilegal di tempatnya bekerja atau orang lain berada, kepada otoritas internal organisasi atau kepada publik seperti media massaatau lembaga pemantau publik. Pengungkapan tersebut tidak selalu didasari itikad baik sang pelapor, tetapi tujuannya untuk mengungkap kejahatan atau penyelewengan yang diketahuinya

Penegakkan hukum terhadap tindak pidana korupsi, kehadiran saksi (termasuk pelapor) sangat diperlukan mengingat sulitnya bagi aparat penegak hukum dalam menyelesaikan suatu tindak pidana yang ditangani apabila tidak adanya kehadiran saksi (termasuk pelapor). Tidak banyak orang yang bersedia mengambil resiko untuk menjadi whistle blower dan mengungkapkan fakta suatu tindak pidana korupsi jika dirinya, keluarganya dan harta bendanya tidak mendapat perlindungan dari ancaman yang mungkin timbul karena pengungkapan kasus tersebut. Begitu pula dengan saksi, jika tidak mendapat perlindungan yang memadai, akan enggan memberikan keterangan sesuai dengan fakta yang dialami, dilihat, dan dirasakannya sendiri.

Saksi dalam peradilan pidana menempati posisi kunci, sebagaimana terlihat dalam penempatannya dalam Pasal 184 KUHAP. Sebagai alat bukti utama, tentu dampaknya sangat terasa bila dalam suatu perkara tidak diperoleh saksi. Pentingnya kedudukan saksi dalam proses peradilan pidana, telah dimulai sejak awal proses peyelidikan dalam peradilan pidana. Begitu pula dalam proses selanjutnya, ditingkat penyidikan, penuntutan sampai pada pemeriksaan di pengadilan, keterangan saksi sebagai alat bukti utama menjadi acuan hakim dalam memutus bersalah atau tidaknya terdakwa.

Kedudukan whistle blower yang demikian penting ini nampaknya sangat jauh dari perhatian masyarakat maupun penegak hukum. Harus diakui bahwa terungkapnya kasus pelanggaran hukum sebagaian besar berdasarkan informasi dari masyarakat. Sudah saatnya whistle blower diberi perlindungan secara hukum, fisik, maupun psikis. Melihat pentingnya perlindungan whistle blower dalam pemberantasan tindak pidana korupsi, di Indonesia ada beberapa hal yang telah diatur mengenai hal tersebut yakni tertuang dalam peraturang perundangundangan yang berlaku, pada Bab V pasal 41.

Walaupun telah ada peraturan perundang-undangan yang mengatur mengenai perlindungan hukum bagi saksi (termasuk pelapor) dan korban dalam upaya pencegahan dan pemberantasan tindak pidana korupsi, tetapi hal melindungi sang pengungkap fakta (whistle blower) tersebut belum jelas dan kurang memadai dalam 
melindungi whistle blower tersebut di Indonesia. Karenanya perlu diatur secara komprehensif perlindungan terhadap pengungkap fakta (whistleblower) dalam satu undang-undang khusus.

Secara umum pengertian whistle blower adalah orang-orang yang mengungkapkan fakta kepada publik mengenai sebuah skandal, bahaya, malpraktik, mal-administrasi maupun korupsi. Para whistle blower ini sangat rentan akan intimidasi dan ancaman karena status hukumnya (di indonesia) tidak diakui. Dalam kasus pidana korupsi, mereka biasanya disebut sebagai para pelapor (dikatagorikan saja secara sederhana berdasarkan KUHAP)

Berkaitan dengan uraian tersebut, maka penulis tertarik untuk meneliti masalah tersebut agar para pengungkap fakta (Whistle blower) tidak merasa takut dan ragu lagi dalam mengungkap kasus korupsi yang diketahuinya dan menuliskannya dalam judul "Perlindungan Hukum Terhadap Whistle blower Dalam Pemberantasan Tindak Pidana Korupsi".

\section{Rumusan Masalah}

Berdasarkan latar belakang adapun rumusan masalahnya yaitu:

Bagaimana bentuk perlindungan bagi whistle blower dalam sistem peradilan pidana di Indonesia?

\section{B. METODE PENELITIAN}

\section{Teknik Pengumpulan Data}

a. Field Research (Penelitian Lapangan), yaitu penelitian yang dilakukan untuk memperoleh data primer dan data sekunder. Data primer dikumpulkan penulis melalui wawancara langsung dengan pihak-pihak yang berkompeten.

b. Library Research (Penelitian Kepustakaan), yaitu penelitian yang dilakukan untuk memperoleh data sekunder lainnya, yakni dengan membaca dan menelaah berbagai bahan pustaka dan mempelajari berkas perkara yang ada hubungannya dengan objek yang akan dikaji.

\section{Analisis Data}

Data yang diperoleh baik secara data primer maupun data sekunder dianalisis dengan teknik kualitatif kemudian disajikan secara deskriptif yaitu menjelaskan, menguraikan, dan menggambarkan sesuai dengan permasalahan yang erat kaitannya dengan penelitian ini.

\section{PEMBAHASAN}

Bentuk perlindungan bagi whistle blower dalam sistem peradilan pidana Indonesia yaitu:

\section{Perlindungan yang Bersifat Represif}

Bentuk perlindungan represif meliputi perlindungan hukum yang diberikan terhadap whistle dalam segi antisipasi dari segala tindakan atau resiko yang tidak 
diinginkan. Hal ini sesuai dengan esensi buku karya Mudakkar bahwa perlindungan yang diberikan negara antara lain represif dan preventif. Perlindungan yang diberikan dalam bentuk secara yuridis maupun fisik.

Sistem perlindungan antisipasi atau represif dengan memanfaatkan lembaga atau badan yang telah ada melalui penambahan bahkan menguatkan fungsi dan kewenangan dari lembaga tersebut. Butuh suatu terobosan sebagai model perlindungan baik pada saksi dan korban terutama whistle blower. Suatu aktivasi lembaga ini sudah di nanti-nanti agar mampu memfasilitasi perlindungan bagi whistle blower.

Lembaga Perlindungan Saksi dan Korban, yang telah dibentuk pasca dikeluarkan Undang-undang Nomor 13 tahun 2006 tentang Perlindungan Saksi dan Korban, belum memberikan suatu jaminan perlindungan secara maksimal. Perlindungan baik dalam bentuk fisik maupun hukum tidak terlaksana dengan efektif. Perlindungan hukum tidak akan terlaksana jika tidak ada motor penggerak untuk mewujudkan suatu jaminan perlindungan hukum, dengan begitu dibutuhkan lembaga atau badan yang mampu melaksanakan.

Atas nama suatu badan yang memiliki suatu AD/ART tersendiri dan tidak patut jika dilakukan suatu intervensi pada lembaga tersebut. Good governance sebagai asas yang merupakan dasar dalam menjalankan tugas dan kordinasi dari seluruh lembaga bahwa tidak diperbolehkan suatu lembaga melakukan intervensi pada lembaga lain. Untuk itu sebagai suatu lembaga, Lembaga Perlindungan Saksi dan Korban dapat menggunakan hak dan wewenangnya untuk menciptakan suatu perlindungan hukum bagi whistle blower.

Di sisi lain model koordinasi antara Lembaga Perlindungan Saksi dan Korban atau LPSK dengan instansi lain dalam memberikan perlindungan hukum dapat digunakan sebagai upaya preventif agar mampu menciptakan instrumen guna mengantisipasi kemungkinan terburuk dalam kedudukan whistle blower. Asas-asas umum pemerintahan yang baik menjadi dasar agar tercipta koordinasi yang harmonis demi kepentingan negara sebagai kebutuhan publik. Dari sinergitas tersebut dapat dihasilkan suatu program maupun kebijakan lembaga agar menciptakan suatu pembebasan dalam pertanggungjawaban pidana yang dipikul (suatu kondisi ketika whistleblower tersangkut kasus dimana ia juga menjadi saksi pengungkap fakta).

Jenis instrumen yang dapat dihasilkan antara Lembaga Perlindungan Saksi dan Korban dengan lembaga lain misal Kejaksaan, melalui Kejaksaan Agung memunculkan suatu kebijakan guna melindungi status whistle blower. Aplikasinya berupa pembuatan ketentuan peraturan yang berisi penempatan whistle blower sebagai bagian dari penuntut umum atau dari pihak kejaksaan. Sehingga demi kelangsungan tugas dan keberhasilan mengungkap suatu kejahatan serta diperoleh pertanggungjawaban dari diri pelaku maka dalam aturan tersebut dimunculkan kekebalan hukum atau legal imunity dari segala upaya hukum yang 
ditujukan padanya. Dalam ketentuan tersebut juga dicantumkan batasan perlindungan hukum yang diberikan oleh keduanya, agar tidak timbul suatu chaos ketika terbit seorang whistle blower dengan segala ancaman yang ditujukan.

Jenis koordinasi lain melalui lembaga representasi masyarakat dengan Lembaga Perlindungan Saksi dan Korban yaitu menempatkan klausula pengaturan seperti di atas atas binding power atau memiliki kekuatan hukum mengikat ketika aturan yang demikian semakin dikembangkan oleh badan representatif masyarakat. Bahwa whistle blower rbukanlah seorang saksi maka pengaturannya harus secara khusus dengan diaplikasikan pada kewenangan LPSK. Dengan begitu tercipta suatu aturan yang lebih tinggi karena dihasilkan oleh lembaga yang memiliki suara atas nama rakyat.

Klausul tersebut memberikan dampak yang sangat obyektif bagi whistle blower dengan sistem perlindungan hukum yang bertaraf legal national. Implikasi yuridis yang timbul bahwa lex specialis derogat legi generalle dan lex superior derogat legi inferiori. Pengaturan yang dilakukan koordinasi Lembaga Perlindungan Saksi dan Korban dengan Kejaksaan masih di bawah pengaturan yang dihasilkan pengaturan oleh legislatif nasional. Pengaturan ini diharapkan mampu memberikan pengamanan bagi seorang whistle blower demi kedudukan dan status hukum.

Selanjutnya penguatan di tubuh Lembaga Saksi dan Korban juga perlu diteguhkan agar tidak terombang-ambing dalam suatu kondisi yang tidak pasti pada suatu saat terjadi kemungkinan yang buruk manipulasi dari berbagai pihak. Badan ini rawan suatu tindakan yang mal administrasi dan tersusup tindakan politik hukum yang merongrong kedudukan whistle blower. Sisi yang perlu ditingkatkan kekuatannya antara lain sumber daya manusia yang lebih profesinal dan capability, kekuasaan mandiri dan instrumen hukum yang jelas dan terakui aplikasinya.

\section{Perlindungan yang Bersifat Represif}

Bentuk perlindungan selanjutnya berupa penerapan Restorative justice yang termodifikasi. Restorative justice bertujuan untuk mewujudkan pemulihan kondisi korban kejahatan, pelaku dan masyarakat berkepentingan (stakeholder) melalui proses penyelesaian perkara yang tidak hanya berfokus pada mengadili dan menghukum pelaku. Stakeholder disini antara lain saksi, whistle blower dan masyarakat yang mungkin dirugikan.

Proses peradilan pidana yang bersifat restoratif berpandangan bahwa mewujudkan keadilan bukan urusan pemerintah dan pelaku kejahatan, tetapi lebih dari itu harus memberikan keadilan secara totalitas yang tidak bisa mengabaikan kepentingan dan hak-hak dari korban dan masyarakatnya.

Mekanisme restorative justice termodifikasi digunakan sesuai dengan karakter bangsa Indonesia karena konsep restorative justice yang ada jika diterapkan maka dapat mengakibatkan efek negatif tanpa mempedulikan karakter bangsa ini. Modifikasi yang dilakukan pada tahap peradilan pidana maupun konsep bentuk perlindungan bagi whistle blower. Tahapan proses peradilan pidana Indonesia sudah 
waktunya untuk direvisi demi tuntutan tujuan hukum yang memberikan kemanfaatan dan keadilan bagi keseluruhan pihak.

Tahap proses peradilan yang akan direvisi dalam bentuk menambahkan ataupun mengganti tahap yang sudah selayaknya untuk dimodifikasi. Pertama akan ditambahkan proses permulaan peradilan sehabis dilakukan penyidikan namun sebelum masuk ke proses penuntutan berupa proses untuk mempertemukan para pihak (stakeholder) baik pelaku, korban maupun kelurga korban, saksi maupun whistle blower sampai masyarakat kolektif yang memiliki kepentingan di dalamnya. Proses ini bisa disebut istilah mediasi dalam proses peradilan perdata ataupun dismissal proses dalam bidang peradilan Tata Usaha Negara.

Dalam proses permulaan tersebut dapat disepakati bahwa baik pihak keluarga korban, korban, saksi, masyarakat kolektif dan pelaku untuk tidak meneruskan kasus kejahatan sampai pada tahap penuntutan. Yang terpenting disini adalah kepentingan para pihak akhirnya mampu lebih banyak diakomodir dan bisa menciptakan kemanfaatan bagi para pihak.

Proses selanjutnya yang sebaiknya ditambah dalam sistem peradilan pidana Indonesia adalah memberikan jaminan perlindungan hukum bagi seorang whistle blower. Kelonggaran yang bisa diberikan dalam sistem peradilan pidana ini bisa berupa tidak diambil sumpah dalam keterangan whistleblower. Untuk menguatkan hal tersebut juga perlu suatu instrumen hukum sebagai payung hukum adanya perlindungan tersebut agar muncul legalitas dalam pengaturan suatu mekanisme beracara di peradilan pidana.

Konsep restorative justice terekstrim adalah dalam hal perundangan yang mengatur. Kemungkinan yang terjadi adalah revisi klausul dalam Undang-undang Nomor 13 tahun 2006 yang memang sesuai perkembangan beberapa tahun belakangan sudah terdapat beberapa hal baru yang tidak dapat diakomodir dengan undang-undang tersebut. Kemungkinan kedua dan yang terberat adalah membuat undang-undang baru yang mengatur tentang whistle blower sehingga muncul payung hukum bagi perlindungan hukumnya.

\section{PENUTUP}

\section{Kesimpulan}

Bentuk perlindungan hukum yang tepat bagi whistle blower dalam system peradilan pidana di Indonesia yaitu bersifat represif dan preventif. Perlindungan yang bersifat represif berupa aktivasi Lembaga Perlindungan Saksi dan Korban sedangkan perlindungan yang bersifat preventif berupa revisi tahapan proses peradilan pidana di Indonesia dan pembentukan undang-undang yang secara khusus mengatur perlindungan hukum bagi whistle blower. 


\section{Saran}

1. Whistle blower sebagai saksi kunci harus mendapat reward atas jasa mengungkapkan fakta kejahatan dan telah berperan sebagai cooperating person dalam proses peradilan pidana. Reward dalam bentuk perlindungan hukum berupa pembebasan pertanggungjawaban ketika seorang whistle blower ternyata dalam pengembangan penyidikan ditemukan bukti bahwa whistleblower bersalah.

2. Pengaturan tentang perlindungan hukum bagi whistle blower harus diatur secara legal sesuai dengan perkembangan restorasi hukum guna menciptakan keadilan sosial bagi seluruh stakeholder dan sebagai tujuan hukum.

\section{Daftar Pustaka}

\section{Buku:}

Adami, Chazawi. 2002.Pelajaran Hukum Pidana 1. Jakarta.Raja Grafindo Persada Ahmd Dinar, KPK dan Korupsi (dalam Studi Kasus), Jakarta: Cintya Press-, 2012. Artidjo, Alkostar.2007. "Restorative Justice". Jurnal Varia Peradilan Majalah Hukum tahun ke-XXII no.262. Jakarta. IKAHI

Friedrich, Carl Joachim (terjemahan Raisul Muttaqien).2010. Filsafat Hukum Perspektif Historis. Bandung. Nusa Media

Leopold, Luhut Hutagalung.2009."Kontroversi Penerapan Pasal 2 UU PTPK (Undang-Undang tentang Pemberantasan Tindak Pidana Korupsi UU NO.31 Tahun 1999 jo. Undang-Undang no.20 tahun 2001)". Jurnal Varia Peradilan Majalah Hukum tahun ke-XXII no.262. Jakarta.IKAHI

Muhadar, Edi Abdullah, Husni Thamrin. 2009. Perlindungan Saksi dan Korban dalam Sistem Peradilan Pidana.Surabaya.CV. Putra Media Nusantara

Peter Mahmud marzuki. 2005. Penelitian Hukum. Kencana Prenada Media. Jakarta.

Romli Atmasasmita, Sekitar Masalah Korupsi Aspek nasional dan Aspek Internasional, Bandung: Mandar Maju, 2004.

Sudarto. 1990.Hukum Pidana 1. Semarang. Yayasan Sudarto Fakultas Hukum Undip Semarang

Wijaya, Firman Whistle Blower dan Justice Collaborator Dalam Perspektif Hukum, Penaku Januari 2012

Wirjono, Prodjodikoro. 2002. Asas-asas Hukum Pidana Di Indonesia. Bandung. Refika Aditama Bandung 


\section{Undang-Undang:}

K U H P

Undang-undang No. 8 Tahun 1981 tentang Hukum Acara Pidana

Undang-undang No.13 Tahun 2006 tentang Perlindungan Saksi dan Korban

\section{Internet:}

http://prasxo.wordpress.com/2017/02/17/definisi-perlindungan-hukum/.

Diakses pada 1 Desember 2017. Pukul:13.20

http://www.shvoong.com/law-and-politics/criminal-law/2027069-pengertian-sistemperadilan-pidana/\#ixzz1LQropZNa.Diakses pada 1 Desember 2017. Pukul: 13.24

Carl Joachim Friedrich.1969.hal 110.Filsafat Hukum: Perspektif Historis.Diakses pada 2 Dember 2017.Pukul:12.30

David Bear.Establishing A Moral Duty to Obey the Law Through a Jurisprudence of Law and Economics.Diakses pada 4 Desember 2017.Pukul 14.53

http://ssrn.com/abstract=1106544.Diakses pada 4 Desember 2017.Pukul 15.02 